\title{
Value chain analysis of non-timber forest products in Baglung district, Nepal
}

\begin{abstract}
A. Paudel ${ }^{1}$, B. P. Subedi ${ }^{2}$, S. Gyawali ${ }^{2}$, G. K. Thapa ${ }^{3}$, and M. B. Sharma ${ }^{3}$
This study was carried out in five Village Development Committees of Baglung district, Nepal. The main objective was to assess the constraints and opportunities to run the non-timber forest products based enterprises, and to design business solutions to make their value chains more efficient and competitive with the best utilization of the available resources. Primary data were collected through group discussions, key informants interview, informal meetings and direct observations, using open-ended questionnaires and checklists. Similarly, secondary data were gathered from reports and records of community forest user groups, District Forest Office and other organizations. The data were analyzed using qualitative and quantitative tools. The identified major constraints concerning the selected value chains are: absence of detailed resource inventory; inadequate knowledge and skills with local people about modern technology and product quality parameters, local resource management policy and sustainable resource harvesting; insufficient finance with local processors; lack of sufficient information about market; and poor infrastructure development. In addition, the study also identified a number of opportunities such as the resource potential and monetary benefits to the local people; financial access through community forest user groups' fund and financial institutions; growing market demand for quality products; involvement of service providers in forest resource management; and supportive policy for employment generation from locally available natural resources. This paper has suggested some business solutions for the effective value chain of selected products.
\end{abstract}

Key words: Business solution, constraints, non-timber forest products, opportunities, value chain

A value chain $(\mathrm{VC})$ is a chain of value-creating activities which are not isolated from one another. Rather, one activity often affects the cost or performance of the others (www.netmba.com). It is a sequence of productive processes from the provision of specific inputs for a particular product to primary production, transformation, marketing and distribution, and final consumption (Amatya, 2009). The products pass through all activities of the chain in order, gaining value with each activity. The value chain analysis (VCA) examines the full range of activities that are required to bring a product in a particular enterprise from its conception to its end markets. A good VCA provides a snapshot of an enterprise at a particular time, while VC mapping indicates the way a product flows from raw material to end markets.

Most of the forest enterprises in developing countries are small and medium enterprises (SMEs) (Elson,
2009), and in many of them, especially those from South Asia, Non-timber forest products (NTFPs) have been identified as one of the potential, high value commodities (Amatya, 2009). More than 700 species have been recognized as NTFPs (Edwards, 1996), and more than 100 types of these are being used in medicinal, aromatic and other industrial preparations are being collected in Nepal for commercial purposes (Poudel, 2009). About 42 thousand tons of over 100 NTFPs are traded, generating over $\$ 30$ million annually (Gurung, 2009).

NTFPs are relatively abundant in rural areas where other income generating opportunities are limited (USAID, 2006). In those areas, NTFPs-based SMEs offer good prospects for enhancing the livelihood and income of local communities (Subedi, 2006). However, the development of an enterprise fulfilling environmental, market and legal requirements can only be facilitated through VCA. To optimize

\footnotetext{
${ }^{1}$ A. Freelance forester, Canada. E-mail: ambipaudel@gmail.com

${ }^{2}$ Asia Network for Sustainable Agriculture and Bioresources, Kathmandu, Nepal

${ }^{3}$ Bhimapokhara Youth Club, Baglung, Nepal
} 
enterprise contribution towards the improvement of livelihoods of poor users, who have been mostly raw material suppliers, would require the identification of bottlenecks in VC and deconstricting them.

In this study, NTFPs refer to the traded parts of plants other than timber, fuelwood and fodder, as per the definition of Master Plan for the Forestry Sector (1989). The study foci were: to identify and select major NTFPs in the study site; to classify major actors and their functions within the VCs; to identify potential service providers (SPs), and to design commercially viable business solutions. This paper describes the methodology of VCA and provides business solutions for efficient and effective VC of selected NTFPs from enterprise perspectives.

\section{Materials and methods}

Five Village Development Committees (VDCs) of Baglung district, namely Khunga, Adhikarichaur, Taman, Khunkhani and Bongadovan were selected for the study based on the availability of commercial NTFPs, ecological connectivity and community interest. They were selected through a district level workshop, participated by governmental and nongovernmental organizations (GOs/NGOs) that have been involved in forestry-related activities within the district. Some of these were: the District Development Committee (DDC), the District Forest Office (DFO), the Federation of Community Forest Users, Nepal (FECOFUN), the Cottage and Small Industry Development Board (CSIDB), the Asia Network for Sustainable Agriculture and Bioresources (ANSAB), the Bhaktapur Craft Paper (BCP), the Livelihoods and Forestry Program (LFP), the Nepal Herbs Management Center (HMC) and the Bhimapokhara Youth Club (BYC).

During the first field visit in February-March, 2008, the baseline information was collected from 31 community forest user groups (CFUGs) of the selected VDCs. A group from each CFUG was formed for discussion, and it comprised of the executive committee members, women, lower castes, youths and seniors. During the second field visit (April-June, 2008), information on NTFPs VC was collected through a series of group discussions. Checklists were used to track discussions on the given issues.

Key informant interviews were conducted with NTFPs collectors/harvesters, middle-men, processors and traders, by using open-ended questionnaires. Informal meetings were held with individuals from the District Forest Office (DFO) and concerned Range Post (RP), CSIDB, DDC, FECOFUN, LFP, BCP, ANSAB, BYC, HMC, Agriculture Development Bank, local financial institutions and Community Based Organizations (CBOs). The availability of NTFPs resource was observed in most of the community forests (CFs). Secondary data were obtained from operational plans $(\mathrm{OPs})$ and constitutions, minutes, and other records of CFUGs, DFO and other organizations. The data collected through different methods and from different sources were cross-checked through triangulation to improve the reliability of the results. Both qualitative and quantitative tools were used for data analysis.

\section{Results and discussion}

\section{NTFPs Selection}

Several meetings and discussions with CFUG members and other stakeholders were conducted and secondary data were reviewed to identify the potential NTFPs of the study area. A total of 22 NTFPs (excluding duplication) were identified and then narrowed down to 5, through the Attractiveness Matrix and Ranking Matrix analyses.

The Attractiveness Matrix Analysis was carried out with each CFUG separately, by reckoning the number of beneficiaries and potential for increase in income and later compiled into a single matrix. The matrix revealed that Lokta (Daphne spp.) and Allo (Girardinia diversifolia) were the most attractive NTFPs. Following them were Jhyau (Lichen spp.), Khoto (Pine resin), and Nigalo (Arundinaria falcata). These five NTFPs were ranked along a weighing scale of 1 to 5 (where 1 was for the least important criterion) and a rating value for each product to derive a cumulative score. The cumulative scores from each study site were averaged to derive a total weighted score for the district (Table 1). The results suggested that the total weighted scores for Lokta was highest at 73 while Khoto received the lowest score of 37 . In this paper, only the first two NTFPs, Lokta and Allo, have been selected for the VC analysis of the major NTFPs.

\section{Lokta}

Lokta is a wild shrub which grows gregariously and abundantly in most Himalayan forests of Nepal between altitudes of 2,000 to 4,000 m (Subedi et al., 
Table 1: Results from Ranking Matrix

\begin{tabular}{|c|c|c|c|c|c|c|}
\hline \multirow{2}{*}{ Criteria } & \multirow{2}{*}{ Weight } & \multicolumn{5}{|c|}{ Proposed VC } \\
\hline & & Allo & Lokta & Jhyau & Nigalo & Khoto \\
\hline $\begin{array}{l}\text { Growth Potential (market, production, } \\
\text { competition) }\end{array}$ & 5 & $4(20)$ & $4(20)$ & $3(15)$ & $2(10)$ & $2(10)$ \\
\hline $\begin{array}{l}\text { Scope (producer, area, income, } \\
\text { consumption) }\end{array}$ & 3 & $4(12)$ & $5(15)$ & $4(12)$ & $3(9)$ & $3(9)$ \\
\hline $\begin{array}{l}\text { Poverty reduction potential, social } \\
\text { benefits }\end{array}$ & 4 & $3(12)$ & $5(20)$ & $3(12)$ & $3(12)$ & $2(8)$ \\
\hline $\begin{array}{l}\text { Prospects for success, } \\
\text { conducive policy and social environment }\end{array}$ & 2 & $4(8)$ & $5(10)$ & $3(6)$ & $3(6)$ & $3(6)$ \\
\hline Traditional knowledge and skill & 2 & $4(8)$ & $4(8)$ & $2(4)$ & $4(8)$ & $2(4)$ \\
\hline Total Weighted Score & & 60 & 73 & 49 & 45 & 37 \\
\hline
\end{tabular}

2006). It is a self-regenerating plant; once harvested, it takes about 6 to 8 years to be fully matured and ready for extraction. An estimated figure of 110, 481 MT (metric ton) of raw Lokta is available in Nepal; however, only about 800 to 1,000 MT are collected each year (HANDPASS, 2003, quoted in Banjara, 2007). In Baglung district too, there is less collection of Lokta than what was available. As reported by BCP, only about $5 \mathrm{MT}$ is harvested each year from Baglung and the two adjoining districts (Parbat and Myagdi) although there was a potential to harvest 90 MT.

Lokta paper, manufactured from the inner bark of the plant, is made in remote hilly areas by the local farmers at a household level or by entrepreneurs on a large scale. In recent years, many CFUGs have also started to produce the paper on larger scales by establishing community-based enterprises (Gauli and Baral, 2008). The price of paper was found to vary in different locations depending mainly on the extent and type of transportation facilities to the market; quality and quantity of paper that can be supplied; and the dealings with contractors and local producers. Lokta prices were higher in the capital because of the additional cost levied on them in terms of taxes and transportation (Olsen and Helles, 1997). During the field study, the average price per kori (200 sheets) paper, based on quality of the paper, ranged between NRs. 1400 and 1800 (US\$1 is about NRs. 70) in Kathmandu while the same ranged between NRs. 900 and 1500 in Baglung.

Historically, Lokta paper has been used for most of the government documents and religious texts in Nepal. Nowadays, it is used mainly for producing stationery products, wrapping papers, boxes and bags, greeting cards, Thankas (Tibetan paintings) and wallpapers. According to Banjara (2007), $90 \%$ of the paper products made in Katmandu were exported mostly to Europe and America while the remaining $10 \%$ were consumed locally.

\section{Allo}

Allo is a fiber yielding wild herb also known as Himalayan Nettle. It grows in high mountain regions of Nepal at an altitude of $1,200 \mathrm{~m}$ to $3,000 \mathrm{~m}$ flourishing under the shades of mixed deciduous forests (www.everesthandicraft.com). When harvested correctly, Allo regenerates abundantly the following year. Out of the many NTFPs, it has been identified as one of the resources with potential for rural enterprise development and a base for sustainable livelihoods of the rural areas (MEDEP, 2001).

Like the Lokta paper, the price of Allo products also varied with the market parameters and locality. During our study, the price of thread ranged between NRs.

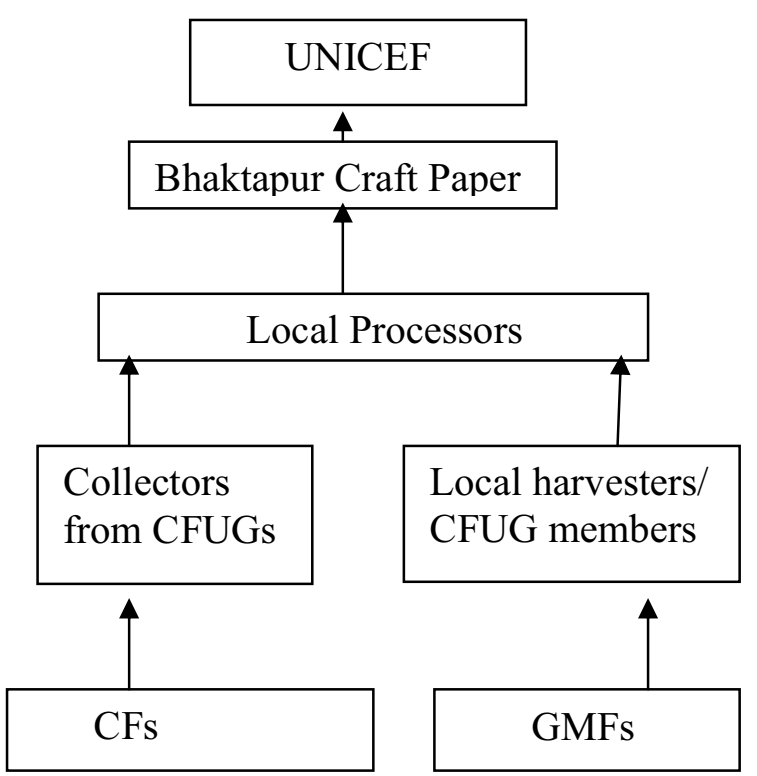

Fig. 1 : Value chain map of Lokta 
300 and 400 per kg in Baglung; and between NRs. 450 and 600 in Parbat. This plant has provided raw material for making most of the textiles needed by households for generations. Local people mainly spun the Allo fiber to weave jackets, porter's headbands, fishing nets, ropes, snacks bags, mats, etc. Other uses of this plant were as vegetable of young shoots by poor people and for animal fodder with leaves and shoots.

\section{Value chain map}

A two-phased process for developing the VC map was carried out: (a) initial basic mapping after the desk review and the first visit; and (b) adjusted mapping including revisions based on group discussions, key informants interview and feedback from groups and individuals brought into the analysis process. The VC maps of Lokta and Allo are depicted in Figure 1 and Figure 2.

Four main types of actor were involved in VC of these products: 1) collectors/harvesters 2) local processors 3) local traders/urban wholesalers and 4) national traders/urban exporters. Each actor added value to the product along the $\mathrm{VC}$ from the transformation of raw material ultimately into marketable finished products. However, the share of benefits that collectors received was significantly lower than those received by other actors (Biggs and Messerschmidt, 2003). In the study site, Lokta collectors sold dried bark to local paper producers, while few of them sold to traders who transported directly to the capital. In Taman VDC, there were about 60 household-level paper producing units where entire family members were involved in paper making or collecting barks from their own forests. $\mathrm{BCP}$, Baglung purchased all the paper sheets from them and delivered to their head office in the Kathmandu valley, where various products and supplies, most of them to United Nations Children's Fund (UNICEF), were manufactured. UNICEF's Greeting Cards Operation is BCP's primary wholesale market, accounting for approximately $90 \%$ of sales, under an exclusive contract.

As per Allo, only CFUGs members harvested it from their own forests. Sometimes, they along with the local people collected it from government managed forests (GMFs) and farm lands. Most of the collectors sold dried bark to either processors or traders, but a few made thread themselves. Thread was the final product of Allo in the study site as there

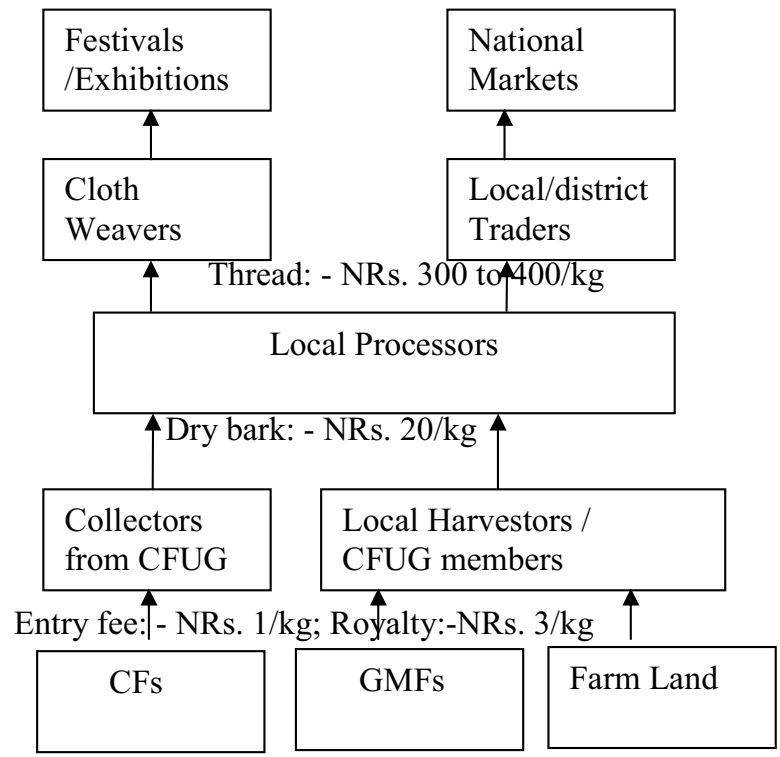

Fig. 2: Value chain map of Allo

was no cloth weaving enterprise till now. Local processors sold thread to either local traders or to cloth weavers in the nearby villages. The traders sold the thread to cloth weaving companies in the capital. The cloth weavers of the neighbouring village have been selling their products mainly during festivals and local exhibition programs and, therefore, do not have fixed markets.

Communities received almost all the required NTFPsbusiness development services directly from facilitating organization in remote parts of Nepal (Gyawali and Panta, 2007). In Baglung too, there were many SPs involved in Lokta and Allo VCs. The Department of Forest (DoF) and its sub-ordinates (DFO, RP) provided technical and legal support throughout the whole chain. Similarly, the concerned CFUGs were also active in raw material production and legitimate collection. Other organizations such as BYC, HMC, CSIDB, LFP, and FECOFUN were also providing support services to local people in processing. In addition, $\mathrm{BCP}$, since its establishment in 1990, has assisted paper processors with input supply such as caustic soda. ANSAB started its work in Baglung for Lokta VC promotion from 2001. It has been active for the VC promotion during this study period mainly in NTFPs inventory, enterprise plan development and marketing.

\section{Opportunities and constraints}

VCA can be used by grassroot organizations to increase knowledge of opportunities and constraints throughout the chain and it can also contribute to 
strategic learning for enterprise development (Mayou, 2003). In this study, major constraints for running Lokta and Allo-based enterprises were identified and possible opportunities were explored. Business solutions have been recommended and are discussed under the following sub-headings of the major components of an enterprise.

\section{Technology and product development}

Rural people have been making Lokta paper with traditional technology and have borne the relatively high cost of production. Moreover, most of them were compelled to sell the paper at low prices mainly because of the low quality resulting from a lack of knowledge about quality parameters. Subedi et al., (2006) had recommended training for paper producers on paper production and quality management. The promotion of quality papermaking has the potential to enhance their economic status (Banjara, 2007). The authors had recommended refresher training about BCP paper quality to increase paper price, and the demonstration and promotion of modern technology such as the beater machine to reduce the cost of production. The presence of some trained persons, who could run beater machine manually in the nearby villages, is an opportunity.

The Allo processing system adopted in the study site was also a traditional one, consisting of self-made, hand-operated machines (Firfire, Hate Charkha) which, according to key informants, were time consuming and increased the cost of unit production. The reasons for using them were their lack of knowledge about modern processing equipments, such as legoperated machine (Khutte Charkha) and spindle with a wheel for spinning fiber and also in understanding quality parameters. These constraints had prohibited them from reaping optimum monetary benefits. Therefore, cost and benefit analysis of traditional and modern methods are recommended and then this information about efficient processing technology and quality parameters should be disseminated. In the study site, none of the processors had made clothes and other textile products as they were not well trained and so they hesitated to prepare them. SPs were suggested to transfer knowledge and skills for product development by organizing trainings, workshops and exposure visits that provide rural people opportunities to learn about modern technology, exchange information, and develop commercial linkages with other actors of VC.

\section{Market access}

The processors in the study site have been selling Lokta paper to BCP for many years. BCP has its own quality grading categories and associated prices. One of the pricing strategies was the use of paper size (i.e. 19.5"* 26"), which was different from the usual size found in the capital. This has indirectly freed the processors to sell the paper exclusively to BCP. However, based on our quick survey, BCP price seemed reasonable considering other benefits provided to processors such as a subsidy on caustic soda and paper transportation costs. Therefore, an alternative market to BCP is not necessary at present; however, the entrepreneurs were encouraged to be aware of the pricing strategy of BCP and to demand for alternative markets. There was no good local market for Allo products and people were selling either Allo bark or thread to interested buyers at their own prices which were usually lower than the market prices.

Poor links to markets, inadequate market information and weak bargaining power were some of the constraints for forest-based SMEs (Elson, 2008). Furthermore, Pandit et al., (2004) pointed out that the inadequate market information was one of the challenges for NTFPs-based enterprises in their study area. This situation was also hampering collectors to get appropriate price (Poudel, 2009). SPs were recommended to provide market information on buyer specification and standardization in regional and national markets and also provide access to new markets and outlets. According to Maraseni et al. (2006), helping collectors with credit, training and market information could be instrumental in teaching them to deal directly with wholesalers, with increased bargaining power and risk-bearing capacity. It is recommended that SPs facilitate the establishment of network among Allo thread makers, cloth weavers, and some entrepreneurs from neighbouring district have been found to be ready to buy threads at good prices.

\section{Input supply}

The abundance of resources with growing market demand suggests a great potential of NTFPs for enterprise development in Nepal (Subedi et al., 2004). However, current practices or level of skills for NTFPs harvest and post-harvest operations were not satisfactory (Subedi, 1999). More than $90 \%$ volumes of the commercial NTFPs were collected from the wild, very often in unsustainable manner (Poudel, 
2009). In the study site, abundant Allo was growing naturally in the forest and surroundings, however, the collectors were harvesting without consideration for the season or the plant condition. Similarly, Lokta collectors also have been harvesting every type and quantity of raw material without considering the sustainability of the resources. This has resulted in low prices because of the poor quality and also the destruction of the resources.

Subedi et al., (2006) had recommended training on sustainable Lokta harvesting and post-harvest handling for the collectors. The authors felt the immediate need for hands-on-training to collectors on sustainable harvesting and the formation of a network of collectors and processors for the regular supply of quality raw material without depleting the natural resources. Lokta processors used caustic soda provided by BCP. Allo processors would also like to use the same, but have been using ashes which they have better access to. However, they were recommended to continue using the same as it takes less time and foreign buyers preferred products cooked in ashes.

\section{Financial access}

The remote areas of Nepal have very few financial institutions, so financial service was a constraint for enterprise development in these areas (Gyawali and Panta, 2007). Although SPs had provided skill development trainings to poor users, often the users could not utilize that skill as a profession because they could neither launch any micro-enterprises on their own nor get any financial assistance from SPs (Paudel and Vogel, 2007). In this study site, local processors were poor and had difficulty in managing funds for buying processing equipment. The NGOs and $\mathrm{CBO}$ had not provided financial support in enterprise development. In terms of opportunities, LFP (donor) has provision for financial support for this sector through either 'quick impact program' or 'machinery support'. Likewise, ADB and local cooperatives have provision to provide loan for forest enterprises. The NGOs and CBOs can disseminate information about these opportunities to communities and can help facilitate access to these loans and financial services.

Some CFUGs with good savings had not being able to mobilize their funds for enterprises such as shares and money lending to poor users at low (or free) rates of interest. This was primarily due to lack of knowledge in investments and, additionally, due to the reluctance of rich users to support poor users. It has been difficult task to convince people to mobilize local resources for the benefit of poor (Maharjan et al., 2004); however, such situation can be greatly improved with facilitation through SPs, as mentioned in a case study in Bhodkhore CFUG, Parbat, by Paudel (2007). Bhodkhore CFUG had started a 'Revolving Fund for poor' program to invest in income generating activities like bamboo-basketry, goat-farming, and the like. We also recommend the establishment of 'enterprise development revolving fund' within enterprise groups or within CFUGs, and to provide orientation to CFUGs about business accounting and fund mobilization. This way, entrepreneurs can have easy access to financial services from all possible sources.

\section{Regulatory policy}

The Forestry Sector Policy (2000) had emphasized the promotion and commercialization of NTFPs, including their export to foreign countries after valueaddition. The policy also encourages local communities to establish forest-based processing enterprises. The government has fixed royalty rates for NTFPs through the Forest Regulation 1995, and these have been revised twice in line with market price of the products. The CFUGs of study site usually sold the products at the government royalty rates. Many CFUGs were not aware of their selling rights, irrespective of the government royalty as mentioned in the Forest Bill of 1990 (Shrestha, 1998). The government had also developed the Herbs and NTFPs Development Policy (2004) with the longterm goal to substantially contribute to Nepalese economy by conserving and preserving high value herbs and NTFPs. Though the policy mentions simplification of tax system for privately grown NTFPs, it das been silent on CFs. There is also a contradiction in controlling taxation system on forest products between Forest Act (1993) and Local Self Governance Act (1999). Multiple taxation also exists due to taxes collected both by central and local governments on NTFPs trade.

Most of the community people in rural parts of Nepal including the site were unaware of the government policy about the use of natural resources. Therefore, it is recommended that awareness raising programs on natural resources policy at local level be conducted. It also seems necessary to provide trainings on right-based approach. With regard to 
marketing, BCP has been helping in legal process because of an agreement with the government for marketing of Lokta from national forest which also includes CF. For Allo, DFO Baglung seemed to be positive for its marketing.

\section{Organizational management}

Until this study was conducted, none of the OPs of CFs had any detailed inventory or management plan for NTFPs and most of them had already expired. Not only was the case in this study site but similar results were also observed in several studies (e.g. Pandit and Thapa, 2004; Kanel and Kandel, 2004). Most of the CFUGs were not able to collect revenue from the NTFPs trade, as their OPs did not sufficiently account for their management and marketing. Therefore, they were suggested to include detailed management plan for NTFPs in OPs and become aware about the legal ownership of their forest resources. As an opportunity, LFP had provisions for financial support for OP revision through DFO/ NGOs. Likewise, ANSAB has also committed to get involved in this process mainly in NTFPs inventory. CFUGs were recommended to exploit these opportunities with the facilitation of SPs.

The collectors/processors in the study site seemed to work individually and were not organized. This has affected their bargaining power and benefits. According to Poudel (2009), profit margins of collectors were less than $10 \%$ of the final price. A formation of sub-group of NTFPs collectors/ processors within CFUGs was recommended to establish their village level network. Social mobilization was also necessary to make the group stronger in organizational development. Support for making an appropriate enterprise model with detail enterprise development plans for each individual enterprise has also been recommended.

\section{Infrastructure development}

Since many high-value NTFPs were located in very remote areas, processing and marketing costs were generally high (Subedi, 1999). Poor infrastructure for product transportation has been one of the major hindrances to the marketing of NTFPs (Poudel, 2009). This also holds true for the study site. However, the construction of earthen roads to the nearby villages was on-going, and this will help for easier transportation. Poor communication and electricity supplies were the other problems hindering the adoption of advanced technologies on enterprise development. The local government was active in supporting infrastructure development. SPs were recommended to lobby for this process.

\section{Conclusion}

Lokta and Allo were the two major NTFPs of the study site. The detailed study of their VCs demonstrated that there was an urgent need for skill development trainings, mainly in sustainable harvesting, processing and products development, and exploring detailed information about the possible markets. The entrepreneurs could be more efficient, increase their productivity and reduce the unit cost of production by using appropriate technology. As local processors were poor, they need basic support services either from CFUGs' fund or from financial institutions. Potential SPs of the study site are suggested to consider the loopholes of VCs, and put an effort to make the NTFPs-based business more competitive and profitable for the sustainable rural livelihoods development.

\section{References}

Amatya, S. M. 2009. Promoting industrial development through trade facilitation. (http:// w w w. un e s cap.org/tid/projects / poverty_amatya.pdf). Accessed on Oct. 09, 2009.

Banjara, G. B. 2007. Handmade paper in Nepal: upgrading with value chain approach. German Technical Cooperation/Private Sector Promotion-Rural Finance. Lalitpur, Nepal.

Biggs, S. D. and Messerschmidt, D. 2003. The culture of access to mountain natural resources: policy processes and practices. Livelihoods Support Program. Working paper 7. Access to Natural Resources Sub-Program. International Centre for Integrated Mountain Development, Nepal.

Edward, D. M. 1996. Non-timber forest products from Nepal: aspects of the trade in medicinal and aromatic plants, FORSEC Monograph 1/96, Forest Research Service Centre, Ministry of Forests and Soil Conservation, Kathmandu, Nepal.

Elson, D. 2008. Linking FLEGT voluntary partnership agreements to jobs and growth: potential challenges and benefits for small and medium sized forest enterprises. Forest Governance, Markets and Trade: Implications for 
Sustainability and Livelihoods. Department for International Development, London, UK.

Elson, D. 2009. Adding value: can FLEGT voluntary partnership agreements lead to increased investment and trade for partner countries? Forest Governance, Markets and Trade: Implications for Sustainability and Livelihoods. Department for International Development, London, UK.

Gauli, K. and Baral, S. 2008. Community Forestry in Nepal: conserving resources with economic incentive. Paper presented in International Conference on Preservation of Bio-cultural Diversity - A Global Issue, May 6-8, BOKU University, Vienna, Austria.

Gurung, P. 2009. Himalayan Biotrade Limited and Aroma Forest: reaching certified international markets for essential oils. In: Linking natural resources, economic growth and good governance. Value chain cases in the context of conservation marketing and certification. Workshop proceedings, June 25-27, Arusha, Tanzania, 28-30.

Gyawali, S. and Panta, N. 2007. A case of Bhimeswore non-timber forest products production and processing enterprise, Dolakha district, Nepal. ANSAB, Kathmandu. Unpublished.

HMGN. 2000. Forestry Sector Policy of 2000. Kathmandu, Law Books Management Board, FDP/ HMGN/USAID.

HMGN. 2004. Herbs and Non-timber Forest Product Development Policy. Ministry of Forests and Soil Conservation, Department of Plant Resources, Herbs and NTFPs Coordination Committee, Kathmandu, Nepal.

Kanel, K. R. and Kandel, B. R. 2004. Community Forestry in Nepal: achievements and challenges. Forest and Livelihood 7(1): 36-48.

Maharjan, M. R.; Acharya, B.; Lamichhane, R. P.; Sharma, N. N.; Pradhan, B. R. and Paudel, T. P. 2004. Operationalization of good governance in Community Forestry: an experience from SAGUN program. In: Twenty-five years of Community Forestry: Contribution in Millennium Development Goal (eds) Kanel, K. R.; Mathema, P.; Kandel, B. R.; Niraula, D. R.; Niraula, A. R.; Sharma, A. R. and Gautam, M., Proceedings of Fourth National Conference of Community Forestry, August 4-6, 2004 in Kathmandu, Nepal, 133-139.
Maraseni, T. N.; Shivakoti, G. P.; Cockfield, G. and Apan, A. 2006. Nepalese non-timber forest products: an analysis of the equitability of profit distribution across a supply chain to India. Smallscale Forest Economics, Management and Policy 5(2): 191-206.

Mayoux, L. 2003. Participatory value chain analysis. Enterprise impact news. Enterprise Development Impact Assessment Information Service. Issue 19, May 2003. (http://www.sed.manchester.ac.uk/ research/iarc/ediais/word-files/EINMay03.doc). Accessed on Oct. 08, 2009.

MEDEP. 2001. Annual Report. Micro-enterprise Development Project, Parbat funded by United Nation Development Program.

MPFS. 1989. Master Plan for the Forestry Sector of Nepal. Ministry of Forest and Soil Conservation, Kathmandu, ADB/ FINNIDA/HMGN.

Olsen, C. S. and Helles, F. 1997. Making the poorest poorer: policies, laws and trade in medicinal plants in Nepal. Journal of World Forest Resource Management 8 (2): 137-158.

Pandit, B. H. and Thapa, G. B. 2004. Poverty and resource degradation under common forest resource management systems in the Mountains of Nepal. Society and Natural Resources 17: 1-16.

Paudel, A. 2007. Role of service providers in Community Forestry Governance. A case study of a community forest users group in Nepal. Masters thesis submitted to the University of Natural Resources and Applied Life Sciences (BOKU), Vienna, Austria.

Paudel, A. and Vogel, S. 2007. Community Forestry Governance in Nepal: A case study of the role of service providers in a community forest users group. A Discussion Paper (DP-34-2007). Institute for Sustainable Economic Development, Department of Economics and Social Sciences, University of Natural Resources and Applied Life Sciences (BOKU), Vienna, Austria.

Poudel, K. L. 2009. Trade potentiality and ecological analysis of non-timber forest products in Himalayan kingdom of Nepal. Accessed on Oct. 11, 2009. (https://repository.unm.edu/ ds pace/bitstream/1928/3300/1/ KrishnaPoudel_EcolAnalysisNTFP.pdf).. 
Shrestha, B. 1998. Changing forest policies and institutional innovations: user group approach in Community Forestry of Nepal. Paper presented in International Workshop on Community-based Natural Resource Management, May 10-14, Washington, D.C., USA.

Subedi, B. P. 1999. Non-timber forest products subsector in Nepal: opportunities and challenges for linking the business with biodiversity conservation. Paper presented in the Workshop on Natural Resources Management for Enterprise Development in Himalayas, August 19-21, Nainital, India.

Subedi, B. P. 2006. Linking Plant-Based Enterprises and Local Communities to Biodiversity Conservation in Nepal Himalaya. Adroit Publishers, New Delhi, India.
Subedi, B. P.; Paudel, S. B. and Gyawali, S. 2006. Handmade paper value chain of Nepal: prospects and challenges in growth, distributional equity and conservation. ANSAB, Kathmandu, Unpublished.

USAID. 2006. Role of natural products in resource management, poverty alleviation and good governance. A case study of Jatamansi and Wintergreen value chains in Nepal. United States Agency for International Development.

Websites:

http://www.netmba.com/strategy/value-chain/ http://www.everesthandicraft.com 